\title{
Ancestral Caddo Ceramic Vessels from Sites in Nacogdoches and Panola Counties in East Texas
}

Timothy K. Perttula

Heritage Research Center, Stephen F. Austin State University

Follow this and additional works at: https://scholarworks.sfasu.edu/ita

Part of the American Material Culture Commons, Archaeological Anthropology Commons, Environmental Studies Commons, Other American Studies Commons, Other Arts and Humanities Commons, Other History of Art, Architecture, and Archaeology Commons, and the United States History Commons

Tell us how this article helped you.

This Article is brought to you for free and open access by the Center for Regional Heritage Research at SFA ScholarWorks. It has been accepted for inclusion in Index of Texas Archaeology: Open Access Gray Literature from the Lone Star State by an authorized editor of SFA ScholarWorks. For more information, please contact cdsscholarworks@sfasu.edu. 


\section{Ancestral Caddo Ceramic Vessels from Sites in Nacogdoches and Panola}

Counties in East Texas

\section{Creative Commons License}

\section{(c) (1) \&}

This work is licensed under a Creative Commons Attribution-NonCommercial 4.0 International License 


\section{Ancestral Caddo Ceramic Vessels from Sites in Nacogdoches and Panola Counties in East Texas}

\section{Timothy K. Perttula}

The ancestral Caddo ceramic vessels discussed in this article are from four different sites in Nacogdoches and Panola counties, in East Texas (Figure 1). The one site in Nacogdoches County, namely the Gatewood site (41NA3) is located in the Angelina River basin, while the three Panola County sites (41PN5, 41PN15, and H. L. English Farm) are on tributaries that flow into the Sabine River.

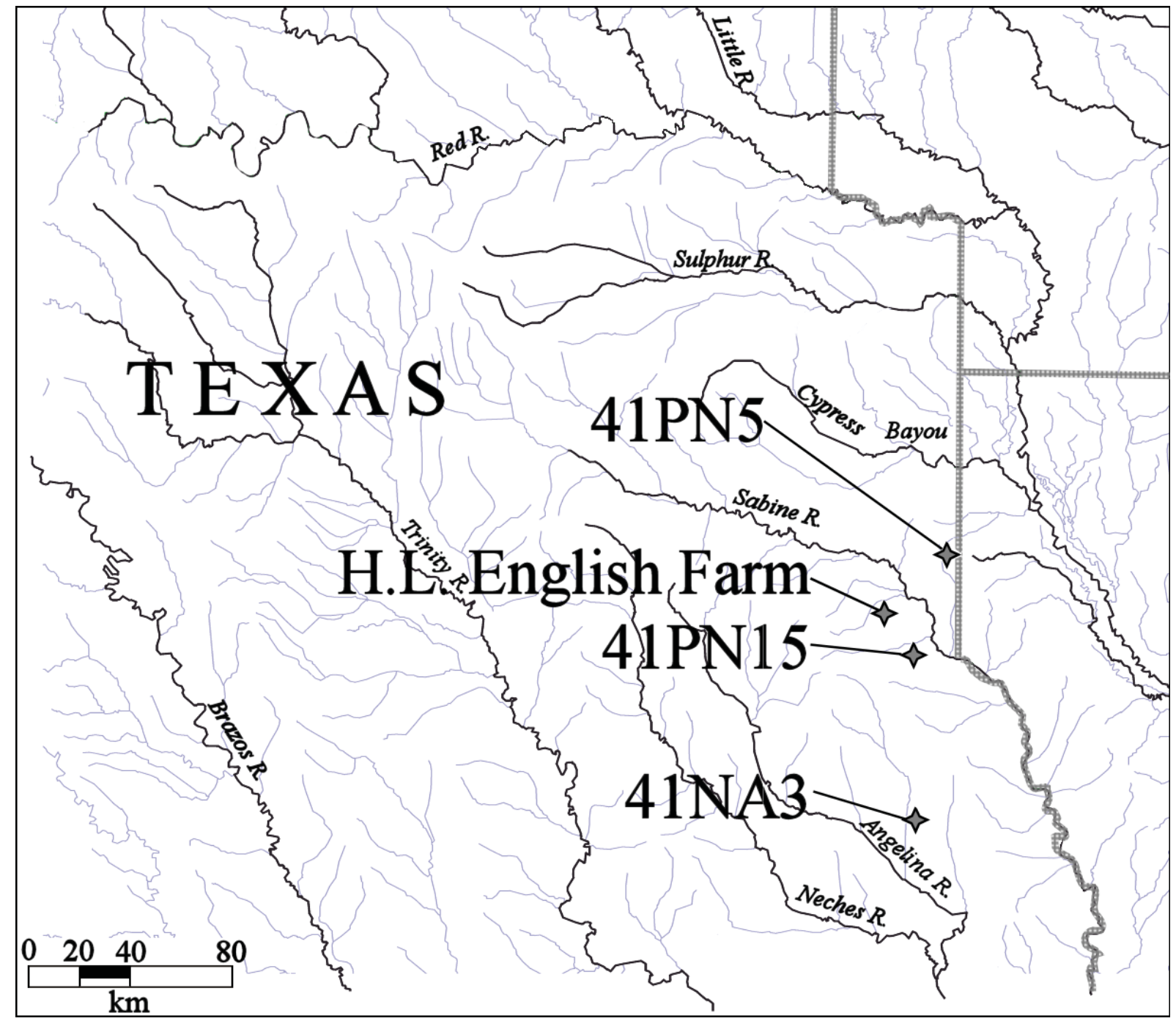

Figure 1. Locations of the Nacogdoches County and Panola County Caddo sites with ceramic vessels discussed in this article. 
The Gatewood site is on the west bank of Attoyac Bayou, a major tributary of the Angelina River basin, in the easternmost part of Nacogdoches County. In 1939, a road grader working along a county road had exposed an ancestral Caddo burial feature with skeletal remains and three ceramic vessels. Gus Arnold, working on the University of Texas Archeological survey of East Texas, recorded the site and collected one of the ceramic vessels; no details were obtained on the other two vessels in the feature.

SITE NAME OR SITE NUMBER: Gatewood (41NA3)

VESSEL NO.: 1

VESSEL FORM: Jar with a short neck

NON-PLASTICS AND PASTE: grog and bone

RIM AND LIP FORM: Everted rim and rounded lip

CORE COLOR: B (fired and cooled in a reducing environment)

INTERIOR SURFACE COLOR: very dark gray

EXTERIOR SURFACE COLOR: very dark gray; fire clouds on the body and base; organic remains on the body

WALL THICKNESS (IN MM): rim, $6.5 \mathrm{~mm}$

INTERIOR SURFACE TREATMENT: smoothed

EXTERIOR SURFACE TREATMENT: none

HEIGHT (IN CM): 11.5

ORIFICE DIAMETER (IN CM): 10.2

DIAMETER AT BOTTOM OF RIM OR NECK (IN CM): 8.8

BASE DIAMETER (IN CM) AND SHAPE OF BASE: $6.4 \mathrm{~cm}$, circular and flat

ESTIMATED VOLUME (IN LITERS): 0.7

DECORATION (INCLUDING MOTIF AND ELEMENTS WHEN APPARENT): The rim of the vessel is plain, and the vessel body has 26 vertical ridged elements.

PIGMENT USE AND LOCATION ON VESSEL: none

TYPE AND VARIETY (IF KNOWN): Belcher Ridged, var. Belcher (see Suhm and Jelks 1962:Plate 6; Kelley 2012:Figure 14-3d). This ceramic type is found in Belcher phase sites as well as contemporaneous non-Belcher phase sites that date from ca. A.D. 1500-1680.

During trenching for a gas pipeline in 1931, an ancestral Caddo burial feature was encountered by a M. E. Shadowen at the T. C. Adams Place (41PN5), and a ceramic vessel from that feature was acquired by The University of Texas in March 1931. The site is on East Socagee Creek, two miles west of the Louisiana state line (see Figure 1). 
SITE NAME OR SITE NUMBER: T. C. Adams Place (41PN5)

VESSEL NO.: 1

VESSEL FORM: Beaker, with a short carinated body

NON-PLASTICS AND PASTE: grog and hematite

RIM AND LIP FORM: N/A

CORE COLOR: G (fired in a reducing environment and cooled in the open air)

INTERIOR SURFACE COLOR: dark gray; fire clouds on the body

EXTERIOR SURFACE COLOR: reddish-brown; fire clouds on the body and base

WALL THICKNESS (IN MM): body, $4.4 \mathrm{~mm}$

INTERIOR SURFACE TREATMENT: none

EXTERIOR SURFACE TREATMENT: smoothed

HEIGHT (IN CM): 14.3+

ORIFICE DIAMETER (IN CM): 7.2

DIAMETER AT BOTTOM OF RIM OR NECK (IN CM): 8.8

BASE DIAMETER (IN CM) AND SHAPE OF BASE: 7.6 $\mathrm{cm}$, circular and flat

ESTIMATED VOLUME (IN LITERS): 0.6+

DECORATION (INCLUDING MOTIF AND ELEMENTS

WHEN APPARENT): The vessel's long neck has four sets of double vertical engraved lines, as well as a single horizontal engraved line above the vessel's carinated body. Pendant from these lines are three sets of three or four concentric semi-circular engraved lines (Figure 2). A single set of three concentric semi-circles is pendant from the horizontal engraved line at the base of the beaker neck.

PIGMENT USE AND LOCATION ON VESSEL: none

TYPE AND VARIETY (IF KNOWN): Unidentified fine ware. Fine ware engraved sherds with this decorative element have been recovered from $14^{\text {th }}$-early $15^{\text {th }}$

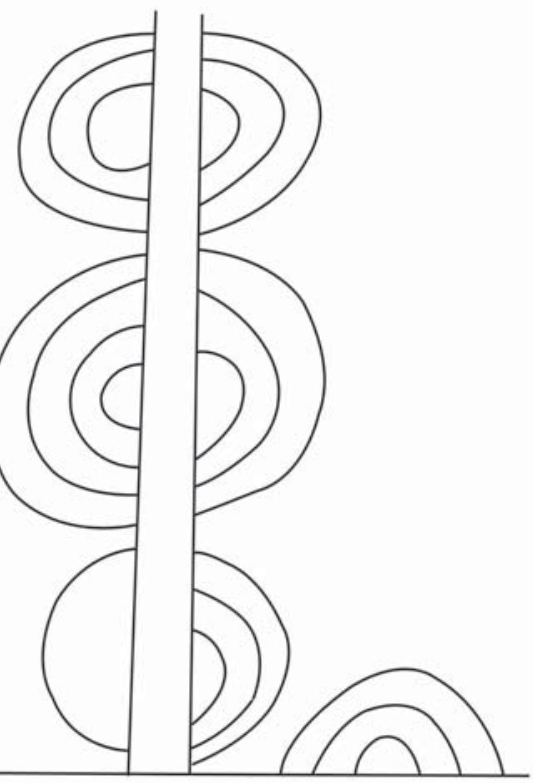

Figure 2. Engraved beaker from the T. C. Adams Place (41PN5).

century A.D. archaeological deposits at the Musgano site (41RK19) in the Sabine River basin (Perttula 2014:Figure 14g, 1). Also, a rim sherd with identical engraved decorative elements has been recovered from the Asa Warner site (41ML46) in the Brazos River basin, and must be from a vessel traded or exchanged by an East Texas Caddo potter to a Central Texas community (Watt 1956:Figure 9:101). The principal component at the Asa Warner site dates from ca. A.D. 1200-1400 (Wright 1997). 
The W. B. Stillwell Farm (41PN15) is on Murvaul Creek, about 10 miles south of Carthage, Texas, and just north of the community of Gary. University of Texas archaeologists learned that whole vessels had been found at two different locations on the farm, and they secured one vessel in April 1931.

SITE NAME OR SITE NUMBER: W. B. Stillwell (41PN15)

VESSEL NO.: 1

VESSEL FORM: Deep bowl; the vessel has two opposed suspension holes (31 $\mathrm{mm}$ in diameter) below the lip NON-PLASTICS AND PASTE: grog

RIM AND LIP FORM: Direct rim and rounded lip

CORE COLOR: G (fired in a reducing environment and cooled in the open air)

INTERIOR SURFACE COLOR: dark grayish-brown

EXTERIOR SURFACE COLOR: reddish-brown; fire clouds on the body and base

WALL THICKNESS (IN MM): rim, $5.5 \mathrm{~mm}$

INTERIOR SURFACE TREATMENT: smoothed

EXTERIOR SURFACE TREATMENT: smoothed

HEIGHT (IN CM): 10.2

ORIFICE DIAMETER (IN CM): 8.9

DIAMETER AT BOTTOM OF RIM OR NECK (IN CM): N/A

BASE DIAMETER (IN CM) AND SHAPE OF BASE: $5.8 \mathrm{~cm}$, circular and flat ESTIMATED VOLUME (IN LITERS): 0.5

DECORATION (INCLUDING MOTIF AND ELEMENTS WHEN APPARENT): There is a single horizontal incised line below the vessel lip, and pendant from that line are four curvilinear incised zones with long, rounded, ends that interlock with a curvilinear hook element (Figure 3). Both the curvilinear incised zones and hook elements are filled with rows of tool and circular punctations.

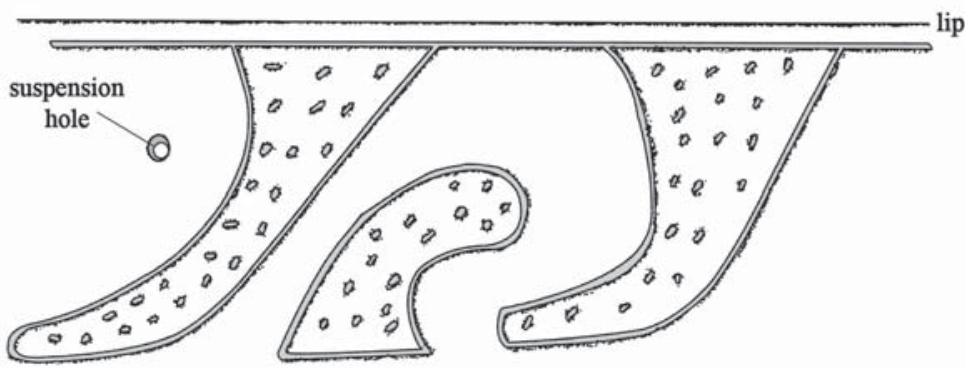

Figure 3. Decorative elements on incised-punctated deep bowl (No. 1) from the W. B. Stillwell site (41PN15).

PIGMENT USE AND LOCATION ON VESSEL: none

TYPE AND VARIETY (IF KNOWN): Unidentified utility ware 
A single ancestral Caddo ceramic vessel was acquired by University of Texas archaeologists in May 1931 from the H. L. English Farm in Panola County. A whole vessel and human remains were found by a Mr. Hubert Plunket of Carthage, Texas, in a ditch on the farm after Spring 1930 flooding. Ceramic sherds were also noted on the site, which is on 6 Mile Creek a few miles southeast of Carthage (see Figure 1).

SITE NAME OR SITE NUMBER: H. L. English Farm (no trinomial assigned)

VESSEL NO.: 1

VESSEL FORM: Jar

NON-PLASTICS AND PASTE: grog

RIM AND LIP FORM: Everted rim and rounded lip

CORE COLOR: G (fired in a reducing environment and cooled in the open air)

INTERIOR SURFACE COLOR: very dark gray

EXTERIOR SURFACE COLOR: brown to reddish-brown; fire clouds on the rim, body, and base; organic remains on the rim and body

WALL THICKNESS (IN MM): rim, $7.4 \mathrm{~mm}$

INTERIOR SURFACE TREATMENT: smoothed

EXTERIOR SURFACE TREATMENT: smoothed

HEIGHT (IN CM): 14.0

ORIFICE DIAMETER (IN CM): 12.7

DIAMETER AT BOTTOM OF RIM OR NECK (IN CM): 12.2

BASE DIAMETER (IN CM) AND SHAPE OF BASE: $7.7 \mathrm{~cm}$, circular and flat

ESTIMATED VOLUME (IN LITERS): 1.1

DECORATION (INCLUDING MOTIF AND ELEMENTS WHEN APPARENT): Plain

PIGMENT USE AND LOCATION ON VESSEL: none

TYPE AND VARIETY (IF KNOWN): Unidentified plain ware

Four ancestral Caddo ceramic vessels in the collections of the Texas Archeological Research Laboratory at The University of Texas at Austin have been documented from sites in Nacogdoches and Panola counties, Texas in this article. They include a post-A.D. 1500 Belcher Ridged jar from the Gatewood site (41NA3) in the Attoyac Bayou basin, a likely Middle Caddo period (ca. A.D. 1200-1400) engraved beaker from the T. C. Adams Place (41PN5), an incised-punctated deep bowl of uncertain type and age from the W. B. Stillwell site (41PN15), and a plain jar from the H. L. English Farm. The Panola County sites are on tributaries of the Sabine River. 
104 Journal of Northeast Texas Archaeology 75 (2017)

\section{References Cited}

Kelley, D. B.

2012 The Belcher Phase: Sixteenth- and Seventeenth-Century Caddo Occupation of the Red River Valley in Northwest Louisiana and Southwest Arkansas. In The Archaeology of the Caddo, edited by T. K. Perttula and C. P. Walker, pp. 411-430. University of Nebraska Press, Lincoln.

Perttula, T. K.

2014 The Caddo Archaeology of the Musgano Site (41RK19) in the Sabine River Basin of East Texas. Special Publication No. 28. Friends of Northeast Texas Archaeology, Pittsburg and Austin.

Suhm, D. A. and E. B. Jelks (editors)

1962 Handbook of Texas Archeology: Type Descriptions. Special Publication No. 1, Texas Archeological Society and Bulletin No. 4, Texas Memorial Museum, Austin.

Watt, F. H.

1956 Archeological Materials from the Asa Warner Sites. Central Texas Archeologist 7:7-29.

Wright, J.F.

1997 The Asa Warner Site (41ML46), McLennan County, Texas. Bulletin of the Texas Archeological Society 68:215-261. 